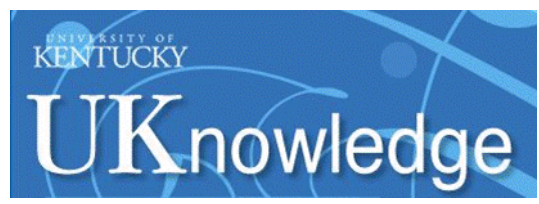

University of Kentucky

UKnowledge

\title{
Soil Microbial Community Response to Hexavalent Chromium in Planted and Unplanted Soil
}

Ioannis Ipsilantis

University of Kentucky

Mark S. Coyne

University of Kentucky, mark.coyne@uky.edu

Follow this and additional works at: https://uknowledge.uky.edu/pss_facpub

Part of the Environmental Microbiology and Microbial Ecology Commons, and the Plant Sciences

Commons

Right click to open a feedback form in a new tab to let us know how this document benefits you.

\section{Repository Citation}

Ipsilantis, loannis and Coyne, Mark S., "Soil Microbial Community Response to Hexavalent Chromium in Planted and Unplanted Soil" (2007). Plant and Soil Sciences Faculty Publications. 6.

https://uknowledge.uky.edu/pss_facpub/6

This Article is brought to you for free and open access by the Plant and Soil Sciences at UKnowledge. It has been accepted for inclusion in Plant and Soil Sciences Faculty Publications by an authorized administrator of UKnowledge. For more information, please contact UKnowledge@lsv.uky.edu. 
Soil Microbial Community Response to Hexavalent Chromium in Planted and Unplanted Soil

\section{Digital Object Identifier (DOI)}

http://dx.doi.org/10.2134/jeq2005.0438

\section{Notes/Citation Information}

Published in Journal of Environmental Quality, v. 36, no. 3, p. 638-645.

The copyright holder has granted the permission for posting the article here. 


\title{
Soil Microbial Community Response to Hexavalent Chromium in Planted and Unplanted Soil
}

\author{
Ioannis Ipsilantis and Mark S. Coyne*
}

\begin{abstract}
Theories suggest that rapid microbial growth rates lead to quicker development of metal resistance. We tested these theories by adding hexavalent chromium [Cr(VI)] to soil, sowing Indian mustard (Brassica juncea), and comparing rhizosphere and bulk soil microbial community responses. Four weeks after the initial $\mathrm{Cr}(\mathrm{VI})$ application we measured $\mathrm{Cr}$ concentration, microbial biomass by fumigation extraction and soil extract ATP, tolerance to $\mathrm{Cr}$ and growth rates with tritiated thymidine incorporation, and performed community substrate use analysis with BIOLOG GN plates. Exchangeable $\mathrm{Cr}(\mathrm{VI})$ levels were very low, and therefore we assumed the $\mathrm{Cr}$ (VI) impact was transient. Microbial biomass was reduced by $\mathrm{Cr}(\mathrm{VI})$ addition. Microbial tolerance to $\operatorname{Cr}(\mathrm{VI})$ tended to be higher in the Cr-treated rhizosphere soil relative to the non-treated systems, while microorganisms in the Cr-treated bulk soil were less sensitive to $\operatorname{Cr}(\mathrm{VI})$ than microorganisms in the non-treated bulk soil. Microbial diversity as measured by population evenness increased with $\operatorname{Cr}(\mathrm{VI})$ addition based on a Gini coefficient derived from BIOLOG substrate use patterns. Principal component analysis revealed separation between $\mathrm{Cr}(\mathrm{VI})$ treatments, and between rhizosphere and bulk soil treatments. We hypothesize that because of $\mathrm{Cr}(\mathrm{VI})$ addition there was indirect selection for fastgrowing organisms, alleviation of competition among microbial communities, and increase in $\mathrm{Cr}$ tolerance in the rhizosphere due to the faster turnover rates in that environment.
\end{abstract}

$\mathrm{C}$ HROMIUM is widely used in industry and a known toxic element (Nriagu and Nieboer, 1988). Trivalent chromium [Cr(III)] and hexavalent chromium [Cr(VI)] are the dominant forms in nature (Bartlett, 1991). Chromium's wide use has caused environmental contamination. However, there are relatively few studies of $\mathrm{Cr}$ effects on the soil microbial community (Viti and Giovanetti, 2001; Shi et al., 2002a; Shi et al., 2002b).

Low molecular weight organic substances, such as root exudates and citric acid have dual effects on $\mathrm{Cr}$ chemistry: reducing $\mathrm{Cr}(\mathrm{VI})$ to $\mathrm{Cr}(\mathrm{III})$, and complexing $\mathrm{Cr}$ (III) and maintaining it in solution (James and Bartlett, 1984). Organic, complexed $\mathrm{Cr}$ (III) may subsequently sorb to Mn oxides and undergo oxidation to $\mathrm{Cr}$ (VI) (James and Bartlett, 1983). Hexavalent Cr is a bioavailable and soluble $\mathrm{Cr}$ form that is toxic to microorganisms, plants, and animals relative to $\mathrm{Cr}$ (III) (Nriagu and Nieboer, 1988). Chromium is not regulated in biosolids by the USEPA because it is typically in the $\mathrm{Cr}$ (III) form and is believed to form stable complexes with organic matter that are not bioavailable in this kind of waste (Chaney et al.,

Dep. of Plant and Soil Sciences, Univ. of Kentucky, Agricultural Science Building, Lexington, KY 40546-0091 USA. Received 22 Nov. 2005. *Corresponding author (mark.coyne@uky.edu).

Published in J. Environ. Qual. 36:638-645 (2007).

Technical Reports: Heavy Metals in the Environment

doi:10.2134/jeq2005.0438

(c) ASA, CSSA, SSSA

677 S. Segoe Rd., Madison, WI 53711 USA
1996). However, Gong et al. (2002) showed toxicity by $\mathrm{Cr}(\mathrm{III})$ to soil microorganisms.

Experiments targeting the rhizosphere microbial communities in metal-contaminated soils are few (Giller et al., 1998). Kozdrój and van Elsas (2000) used artificial root exudates to study the effects of organic compounds on microbial diversity of heavy metal polluted soils. Carlot et al. (2002) isolated Cd-tolerant, plant growthpromoting rhizobacteria from Brassica roots to evaluate potential use in phytoremediation. However, the effects on the whole microbial community were not examined.

Soil microbial communities can be useful bioindicators of soil pollution (Gong et al., 2002), and studying the effects of metals on microbial communities is more direct than measuring metal bioavailability and speciation (Ellis et al., 2002). Soil microbial communities can also indicate the capacity of soil to restore itself and perform certain functions (e.g., organic matter decomposition) after temporary or permanent disturbance (Giller et al., 1998; Griffiths et al., 2000). Babich and Stotzky (1985) indicated that heavy metals reduced microbial biomass and species diversity in soil. In addition, DíazRaviña and Bååth (1996) showed that higher growth rates can lead to faster metal tolerance development. However, the rhizosphere, an environment with high microbial growth rates (Soderberg and Bååth, 1998), has not been examined in light of this hypothesis.

The objective of this experiment was to investigate the effects of $\mathrm{Cr}(\mathrm{VI})$ on bulk and rhizosphere microbial communities. Based on Babich and Stotzky (1985) and Díaz-Raviña and Bååth (1996) we expected Cr(VI) to reduce soil microbial biomass and diversity in both bulk and rhizosphere soil, and increase microbial community tolerance to $\mathrm{Cr}(\mathrm{VI})$ in both soil types, but faster, and therefore to a greater extent in the short-term study we performed for the rhizosphere soil relative to the bulk soil.

\section{MATERIALS AND METHODS}

\section{Treatment of Soil with Chromium(VI) and Development of the Plant Rhizosphere}

Woolper silt loam (fine, mixed, mesic, Typic Argiudoll, 7\% sand, $60 \%$ silt, and $33 \%$ clay, $120 \mathrm{~g} \mathrm{~kg}^{-1}$ organic matter, $\mathrm{pH} 6.7,620 \mathrm{~g} \mathrm{~kg}^{-1}$ water holding capacity) was used in this study. The soil was collected from the surface $5 \mathrm{~cm}$ and sieved moist through a 2-mm sieve. Treatments were: (i) bulk soil; (ii) bulk soil amended with $447 \mathrm{mg} \mathrm{kg}^{-1} \mathrm{Cr}(\mathrm{VI})$; (iii) rhizosphere soil; (iv) rhizosphere soil amended with $447 \mathrm{mg} \mathrm{kg}^{-1} \mathrm{Cr}(\mathrm{VI})$. There were three replicates of each treatment, and all values in this study are reported on a dry-weight soil basis unless specifically noted. The desired $\mathrm{Cr}(\mathrm{VI})$ concentration for this experiment was high, but one that would also allow the plants

Abbreviations: TdR, tritiated thymidine; $\mathrm{Bc}$, biomass $\mathrm{C}$; Ec, extractable C; AWCD, average well color development. 
to grow. Each individual replication of $1 \mathrm{~kg}$ moist soil $(694 \mathrm{~g}$ dry weight basis) was treated with a $\mathrm{K}_{2} \mathrm{Cr}_{2} \mathrm{O}_{7}$ solution by thorough mixing in a rotating shaker, and subsequently dispensed into plastic pots. The control treatments received only water.

Fifteen seeds of Indian mustard were sown in pots intended for rhizosphere soil, and the moisture water content was adjusted to field capacity. After germination, five plants per pot were allowed to grow. All pots were kept in a greenhouse with additional light up to $12 \mathrm{~h}$ per day. Deionized water was added to each pot daily by sub-irrigation to minimize leaching and to prevent the soil from drying. After $4 \mathrm{wk}$, plant shoots were removed, roots with the adhering soil were removed and the rest of the soil (hereafter called rhizosphere soil) was individually mixed for every replicate. In this study the operational definition of the rhizosphere soil was all the soil in the planted pots. This definition differs from the usual terminology, but is supported by James and Bartlett (1984), who indicate that the effect of the rhizosphere on $\mathrm{Cr}$ extends to the rest of soil in a pot. Bulk and rhizosphere soil were stored at $4{ }^{\circ} \mathrm{C}$ for several weeks until further analysis.

\section{pH, Chromium Analysis, and Biomass Measurements}

The methods described by Bartlett and James (1996) were used for $\mathrm{Cr}$ analysis. Duplicate samples were measured for each replicate. Total extractable $\mathrm{Cr}$ was measured after extraction of one $\mathrm{g}$ of soil by $50 \mathrm{~mL}$ of $10 \mathrm{mM}$ monobasic di-potassium citrate buffer $\mathrm{pH} 7.2$ for $72 \mathrm{~h}$, and measured by atomic adsorption spectroscopy. Exchangeable $\mathrm{Cr}(\mathrm{VI})$ was measured colorimetrically at $540 \mathrm{~nm}$ after an adjustment of the $s$-diphenylcarbazide method for use with a microplate autoreader. Labile $\mathrm{Cr}$ (III) was determined by difference. The $\mathrm{pH}$ of each pot was measured in triplicate by glass electrode on air-dried soil in a 1:1 soil/ water paste.

The method of Vance et al. (1987), as modified by Wu et al. (1990), was used for fumigation-extraction. Moist soil was adjusted to $55 \%$ of water holding capacity and incubated in darkness at room temperature for $7 \mathrm{~d}$ in air-tight plastic bags to remove the effects of initial disturbance. Samples were fumigated with $\mathrm{CHCl}_{3}$ vapor for $24 \mathrm{~h}$ and $20 \mathrm{~g}$ were extracted with $0.5 \mathrm{M} \mathrm{K}_{2} \mathrm{SO}_{4}$. Organic $\mathrm{C}$ in the extracts was determined with an automated total organic $\mathrm{C}$ analyzer (Shimadzu 5000A, Kyoto, Japan). Soil biomass C (Bc) was calculated from the extractable $\mathrm{C}(\mathrm{Ec})$ by the equation: $\mathrm{Bc}=2.22 \mathrm{Ec}$ (Wu et al., 1990).

For ATP analysis we extracted microorganisms from soil by diluting $10 \mathrm{~g}$ of soil in $100 \mathrm{~mL}$ sterile distilled water in sterile plastic bags, homogenizing for $5 \mathrm{~min}$ in a Stomacher lab blender (Brinkman Instruments, Inc., Westbury NY), and centrifuging for $10 \mathrm{~min}$ at $750 \mathrm{~g}$ at $5^{\circ} \mathrm{C}$. Fifty $\mu \mathrm{L}$ of the extract were placed into polypropylene cuvettes, along with $50 \mu \mathrm{L}$ of ATP releasing agent (Turner Designs, Sunnyvale CA), $50 \mu \mathrm{L}$ HEPES buffer $\mathrm{pH}$ 7.0, and $100 \mu \mathrm{L}$ luciferine-luciferase (Turner Designs). Standards and blanks were prepared in water or in the extractant. A luminometer (Turner Designs 20/20) was used to measure ATP. The basic concept of this approach is similar to that of the tritiated thymidine procedure modified for soil by Bååth (1992); instead of working with soil itself, the method measures part of the microbial community by working with soil extract and homogenization-centrifugation.

\section{Tritiated Thymidine Incorporation Measurements}

We used the method of Bååth (1992) for tritiated thymidine incorporation (TdR). Tolerance measurements were made in bulk and rhizosphere soil as defined by the working definitions previously mentioned. Six g of soil were homogenized with $60 \mathrm{~mL}$ of sterile distilled water in a plastic bag for $5 \mathrm{~min}$ and centrifuged for $10 \mathrm{~min}$ at $700 \mathrm{~g}$ and $5^{\circ} \mathrm{C}$ in sterile plastic centrifugation tubes. The supernatant was poured through sterile glass wool, and $1.8 \mathrm{~mL}$ was added to plastic vials. $\mathrm{Cr}(\mathrm{VI})$ solutions of different concentrations were added $(0.2 \mathrm{~mL})$ after filter sterilization through $0.22-\mu \mathrm{m}$ polycarbonate filters (Millipore, Bedford, MA). After 15 to $20 \mathrm{~min}$ at room temperature, $100 \mathrm{n} M$ [methyl- ${ }^{3} \mathrm{H}$ ] thymidine $\left(1 \mathrm{mCi} \mathrm{mL}^{-1}\right.$, Amersham, Little Chalfont, England) was added to each vial. Incorporation was stopped after $2 \mathrm{~h}$ by adding $1 \mathrm{~mL}$ of $5 \%$ ice-cold formalin. The formalin was added immediately before the thymidine for zero-time controls. The suspensions were incubated for $15 \mathrm{~min}$ in an ice bath, and filtered through $25-\mathrm{mm}$ cellulose-acetate filters $(0.45-\mu \mathrm{m}$ pore size; Osmonics, Minentonka, MN). The filters were previously soaked in unlabeled thymidine solution for $1 \mathrm{~h}$ to reduce sequestration of radioactive thymidine on the filters of the control with zero time incubation, which was used to account for non-biotic sequestration of label on the filters. The filters were washed three times with $5 \mathrm{~mL}$ of ice-cold $80 \%$ ethanol to remove thymidine bound to lipids, and three times with $5 \mathrm{~mL}$ of ice-cold $5 \%$ trichloroacetic acid to precipitate the macromolecules.

The labeled filters were placed in plastic scintillation vials containing $0.5 \mathrm{~mL}$ of $0.1 \mathrm{M} \mathrm{NaOH}$ and incubated in a $90^{\circ} \mathrm{C}$ water bath for $2 \mathrm{~h}$ to solubilize macromolecules. The vials were allowed to cool, and $5 \mathrm{~mL}$ of Bio-safe II scintillation cocktail was added. The radioactivity was quantified by counting in a Packard 1900 TR liquid scintillation analyzer (Meridian, CT). An external standards method was used to correct for quenching.

Higher TdR incorporation rates can result from higher numbers of bacteria. Therefore, the data were expressed as specific TdR incorporation (STdR), on the basis of TdR incorporation per unit of biomass carbon or ATP using the fumigation-extraction and ATP data. We used only $10 \%$ of the fumigation-extraction biomass carbon, assuming it to be the percentage of soil microbes extracted with the homogenizationcentrifugation method (Bakken, 1985), and the TdR incorporation of the control $\mathrm{Cr}$ concentration.

\section{Community Substrate Use Analysis (BIOLOG GN Plates)}

Six $\mathrm{g}$ of soil were diluted in $60 \mathrm{~mL}$ sterile deionized water in a plastic bag and extracted in a laboratory blender for $5 \mathrm{~min}$. Ten $\mathrm{mL}$ of the extract were further diluted into $90 \mathrm{~mL}$ of $0.85 \% \mathrm{NaCl}$. The diluent was inoculated into BIOLOG GN plates, which were incubated at $25^{\circ} \mathrm{C}$. The color developed was measured using a microplate autoreader (BIO-TEK instruments EL 311) at $630 \mathrm{~nm}$, every $4 \mathrm{~h}$, up to $72 \mathrm{~h}$. One plate for each pot was inoculated.

The average well color development (AWCD) was calculated for each plate for each reading time as the arithmetic average of absorbance values for all 95 wells, after subtracting the value of the blank well from each substrate (Garland and Mills, 1991). If the subtraction gave a negative value, zero was used for that individual well. The AWCD for each treatment and time was the average of the AWCD of the three corresponding plates.

To normalize for different inoculum densities we calculated the Gini coefficient and performed principal component (PC) analysis at 0.75 AWCD (Garland, 1996; Harch et al., 1997), for which the reading of each plate with a value closest to 0.75 AWCD was used. The Gini coefficient was calculated using the formula:

$$
G=\frac{\sum_{i=1}^{N} \sum_{j=1}^{N}\left|x_{i}-x_{j}\right|}{2 N^{2} \bar{x}}
$$


where $x_{i}, x_{j}$ refer to an absorbance value for each of the carbon source wells (1 to 95), $i$ and $j$ are the wells, $N$ is the total number of carbon sources (95), and $x$ is the AWCD (Harch et al., 1997).

\section{Statistical Analysis}

The logarithm of the inhibition concentration that caused $50 \%$ reduction in thymidine incorporation $\left(\mathrm{IC}_{50}\right)$ was calculated by least squares fitting to a logistic model: $A=100 /[1+$ $\left.e^{\mathrm{b}(\mathrm{S}-\mathrm{a})}\right]$ (Doelman and Haanstra, 1989; Díaz-Raviña et al., 1994; Shi et al., 2002a), where $A$ is thymidine incorporation expressed as a percentage of the control, $b$ is a slope parameter indicating inhibition rate, $S$ is the logarithm of Cr concentration, and $a$ is $\mathrm{IC}_{50}$. Instead of zero, a very low $\mathrm{Cr}(\mathrm{VI})$ concentration $\left(10^{-5} \mathrm{M}\right)$, that did not cause inhibition of incorporation, was used as the control (Díaz-Raviña et al., 1994). The $\mathrm{IC}_{50}$ and $b$ values were estimated by using nonlinear regression with the equation above using the SAS MODEL procedure (SAS Institute, Inc., 1989). Principal component analysis was performed using the SAS PRINCOMP procedure. A $2 \times 2$ ANOVA was performed for the major effects (metal and plant) and their interaction, with multiple comparisons using an experiment wise error rate of $\alpha=0.05$ and least significant means with the Tukey adjustment.

\section{RESULTS}

\section{Effects of Chromium on Indian Mustard, Chromium Analysis, and Biomass Measurements}

Metal hydrolysis in soil is an acidifying reaction and the $\mathrm{Cr}(\mathrm{VI})$ treatment stunted the plants, but there was no significant effect on the $\mathrm{pH}$ by the end of the experiment. After 4 wk the extractable Cr was low (Table 1), $12 \mu \mathrm{g} \mathrm{Cr}(\mathrm{VI}) \mathrm{kg}^{-1}$ soil, and $91 \mathrm{mg} \mathrm{Cr}(\mathrm{III}) \mathrm{kg}^{-1}$ soil. In both rhizosphere treatments $\mathrm{Cr}$ (VI) levels were below detection.

Fumigation-extraction and ATP (Table 2) measurements were positively correlated $\left(R^{2}=0.55\right)$, and both methods showed that $\mathrm{Cr}$ addition resulted in lower soil microbial biomass, with no difference in this effect between bulk and rhizosphere soil, as the interaction of the metal with the plant was not significant. The unfumigated controls had significantly higher background microbial carbon in the $\mathrm{Cr}$ treatments, compared with non-Cr-treated soil (data not shown).

Biomass measurements with ATP by homogenization-centrifugation showed the same trend as fumigation-extraction. In contrast to the fumigation-extraction procedure, the effect of $\mathrm{Cr}$ on extractable ATP was more pronounced for the rhizosphere soil, where there was an approximately 10-fold decrease in ATP with $\mathrm{Cr}$ addition (Table 2).

Table 1. Citrate-extractable (labile) $\mathrm{Cr}$ (III) and phosphateexchangeable $\mathrm{Cr}(\mathrm{VI})$ analysis, 1 mo after the $\mathrm{Cr}(\mathrm{VI})$ amendment. $\dagger$

\begin{tabular}{lccc}
\hline Parameter & Cr amendment & $\mathrm{Cr}(\mathrm{III})$ & $\mathrm{Cr}(\mathrm{VI})$ \\
\cline { 2 - 3 } & \multicolumn{2}{c}{$\mathrm{mg} \mathrm{kg}^{-1}$ soil } & \multicolumn{1}{c}{$\mathrm{\mu g} \mathrm{kg}^{-1}$ soil } \\
Rhizosphere & 0 & $\mathbf{0 . 5 ( 0 . 0 7 )}$ & $\mathrm{ND} \ddagger$ \\
Bulk soil & 447 & $20.6(2.5)$ & ND \\
& 0 & $2.0(0.7)$ & $1.9(0.8)$ \\
& 447 & $91.1(9.3)$ & $12.2(2.5)$ \\
\hline
\end{tabular}

$\dagger$ Values are the mean of three replications. Standard deviation given in parentheses.

$\ddagger$ Below detection limit.

\section{Tritiated Thymidine Incorporation}

Overall TdR incorporation in the rhizosphere soil tended to be higher than in the bulk soil, and higher for the Cr treatments, but because of high variability there were no significant differences (Fig. 1, Table 2). When the data were expressed as a percent of the control to measure tolerance, there was no difference in the rate at which $\mathrm{TdR}$ incorporation declined as $\mathrm{Cr}$ concentration increased (Fig. 1). The bulk soil $\mathrm{IC}_{50}$ was higher than that of the Cr-treated bulk soil and the non-treated rhizosphere. The Cr-treated rhizosphere soil $\mathrm{IC}_{50}$ tended to be higher, but was not significantly different than that of the non-treated rhizosphere (Table 2). The variability in the rate of TdR incorporation was high overall.

The specific thymidine incorporation rate (STdR) measured in terms of fumigation-extraction $\mathrm{C}$ revealed that there was a higher incorporation rate in the presence of $\mathrm{Cr}$ for both rhizosphere and bulk soil (Table 2). Expressing STdR per unit fumigation-extraction-C gave incorporation rates four times higher in the Cr-treated rhizosphere soil. Variability was very high for ATP, and although the Cr treatments had much higher STdR, they were not significantly different from the unamended treatments.

\section{Community Substrate Use Analysis (BIOLOG Plates)}

The AWCD reflected the biomass results, because inoculum density is known to affect color development (Garland and Mills, 1991; Haack et al., 1995). The AWCD was slower and lower in samples from Cr treatments (Table 2, Fig. 2). $L$-pyroglutamic acid was the only substrate in which there was faster and higher well color development for the $\mathrm{Cr}$ treatments.

The Gini coefficient, an indicator of microbial evenness, for which higher values reflect less evenness (i.e., less diversity), showed that evenness was higher with $\mathrm{Cr}$ addition, and that there were no differences in evenness between bulk soil and rhizosphere soil (Table 2).

Principal component analysis showed a partitioning of the treatments (Table 2, Fig. 3). The first principal component accounted for $66 \%$ of the variability and was strongly associated with $\mathrm{Cr}$ effects, while the interaction with the plant was also significant (Table 2). The Cr treatments were on the positive part of the PC1 axis, while the non-Cr-treated bulk and rhizosphere soil were associated with the negative part of PC1 (Fig. 3). The plant effect was stronger for $\mathrm{PC} 2$, where rhizosphere treatments had a tendency to associate with positive values relative to the $\mathrm{PC} 2$, and the bulk soil treatments with negative values relative to $\mathrm{PC} 2$.

\section{DISCUSSION}

\section{Chromium Toxicity}

Brassica juncea (Indian mustard) was used, because the Brassica family accumulates heavy metals and also rhizofiltrates Cr(VI) (Dushenkov et al., 1995). Metal hydrolysis is an acidifying reaction but at the concentration used, $\mathrm{Cr}$ had no permanent effect on lowering $\mathrm{pH}$, which has been previously observed (Gong et al., 2002). 
Table 2. Summary of results of: biomass carbon measured by fumigation-extraction (FE), ATP, tritiated thymidine (TdR) incorporation at control $\left(10^{-5} M\right) \mathrm{Cr}(\mathrm{VI})$ concentration, logarithm of $\mathrm{Cr}(\mathrm{VI})$ concentration $(M)$ that caused $50 \%$ reduction in $\mathrm{TdR}$ incorporation (IC $\left.\mathrm{F}_{50}\right)$, the slope-rate of inhibition of TdR incorporation with increasing $\mathrm{Cr}(\mathrm{VI})$ concentration, specific TdR incorporation (STdR) expressed with FE and ATP data, average BIOLOG well color development (AWCD), Gini coefficient at 0.75 AWCD, principal components 1 and 2 (PC-1, PC-2), and $2 \times 2$ ANOVA with interaction table showing $P$ values. Numbers in the same row followed by different letters are significantly different at $\alpha=\mathbf{0 . 0 5}$, as determined by multiple pair-wise comparisons with the Tukey adjustment and experiment-wise error of $0.05, n=3$.

\begin{tabular}{|c|c|c|c|c|c|c|c|}
\hline Parameter & Rhizosphere & Rhizosphere $+\mathbf{C r}$ & Bulk soil & Bulk soil $+\mathbf{C r}$ & Metal & Plant & Metal $\times$ plant \\
\hline FE biomass carbon (mg $\mathrm{C} \mathrm{kg}^{-1}$ soil dry wt.) & 803a & $278 c$ & $562 b$ & 90d & $<\mathbf{0 . 0 0 0 1}$ & $<\mathbf{0 . 0 0 0 1}$ & 0.13 \\
\hline ATP (ng ATP $g^{-1}$ soil dry wt.) & $10.5 \mathbf{a}$ & $1.1 b$ & 7.0ab & 2.4ab & 0.005 & 0.5 & 0.2 \\
\hline TdR (mol TDR ml $\left.\mathrm{ml}^{-1} \mathrm{~h}^{-1}\right) \times\left(10^{-14}\right)$ & $29.0 a$ & 42.1a & $6.9 \mathrm{a}$ & 22.0a & 0.2 & 0.099 & 0.9 \\
\hline $\mathrm{IC}_{50}$ & $-3.51 b$ & $-3.27 \mathbf{a b}$ & $-3.15 a$ & $-3.52 b$ & 0.5 & 0.4 & 0.0043 \\
\hline Slope & $2.89 a$ & $3.25 \mathrm{a}$ & $3.96 a$ & $2.91 \mathrm{a}$ & 0.5 & 0.5 & 0.2 \\
\hline STdR-FE $\dagger$ & $0.6 \mathrm{~b}$ & 2.4ab & $0.2 \mathrm{~b}$ & $4.3 \mathrm{a}$ & 0.005 & 0.3 & 0.18 \\
\hline STdR-ATP $\div$ & 46.1a & $2220 a$ & 16.1a & $226.7 a$ & 0.2 & 0.3 & 0.3 \\
\hline AWCD at $48 \mathrm{~h}$ & $1.21 \mathrm{a}$ & $0.81 b$ & 1.06ab & $0.45 c$ & 0.0001 & 0.009 & 0.19 \\
\hline Gini at 0.75 AWCD & $0.41 \mathrm{a}$ & $0.25 b$ & $0.42 a$ & $0.24 b$ & 0.001 & 0.9 & 0.7 \\
\hline PC-1 & $-5.8 b c$ & $2.0 b$ & $-7.0 \mathrm{c}$ & $10.8 \mathbf{a}$ & $<0.0001$ & 0.067 & 0.024 \\
\hline PC-2 & $0.9 a$ & $3.7 \mathbf{a}$ & $-2.2 \mathrm{a}$ & $-2.4 a$ & 0.4 & 0.017 & 0.3 \\
\hline
\end{tabular}

$\dagger$ With $10 \%$ of biomass $\mathrm{C}$ to reflect biomass of the soil solution, mol $\mathrm{Tdr} \mathrm{mL}^{-1} \mathrm{~h}^{-1} \mathrm{mg}^{-1}$ biomass $\mathrm{C} \times 10^{-18}$.

$+\mathrm{mol} \mathrm{TdR} \times 10^{-14} \mathrm{~mL}^{-1} \mathrm{~h}^{-1} \mathrm{ng}^{-1}$ ATP.

The extractable $\mathrm{Cr}$ was considered the biologically available $\mathrm{Cr}$. One month after the $\mathrm{Cr}$ application the level of $\mathrm{Cr}(\mathrm{VI})$, the highly toxic form, was low, and for this reason it appears that the results represent an 'echo' of the impact of the $\mathrm{Cr}$ application to the soil. The nontreated soil $\mathrm{Cr}$ (III) and (VI) concentrations show natural background $\mathrm{Cr}$ levels, while levels of $\mathrm{Cr}(\mathrm{VI})$ of the treated bulk soil are close to natural levels (Katz and Salem, 1994). The average total Cr concentration in Kentucky soils is $108 \mathrm{mg} \mathrm{kg}^{-1}$ soil (Karathanasis and Seta, 1993). Adsorption and precipitation reactions mediated by clay and organic matter were the most probable reasons why $\mathrm{Cr}$ was no longer plant available, and the nonalkaline soil $\mathrm{pH}$ did not favor the presence of $\mathrm{Cr}(\mathrm{VI})$
(Bartlett and Kimble, 1976). The perturbation caused by Cr was therefore considered transient, much like heat, flood, or fumigation (Griffiths et al., 2000; Ranneklev and Bååth, 2001), rather than persistent, as is the case with other heavy metals (McGrath et al., 1995; Giller et al., 1998). This would not have been the case if the soil used had a capacity to re-oxidize $\mathrm{Cr}$ (III) to $\mathrm{Cr}(\mathrm{VI})$, as did the vegetated tannery soil used by Viti and Giovanetti (2001).

\section{Microbial Biomass Measurements}

Fumigation-extraction and ATP measurements indicated that $\mathrm{Cr}$ significantly reduced microbial biomass.

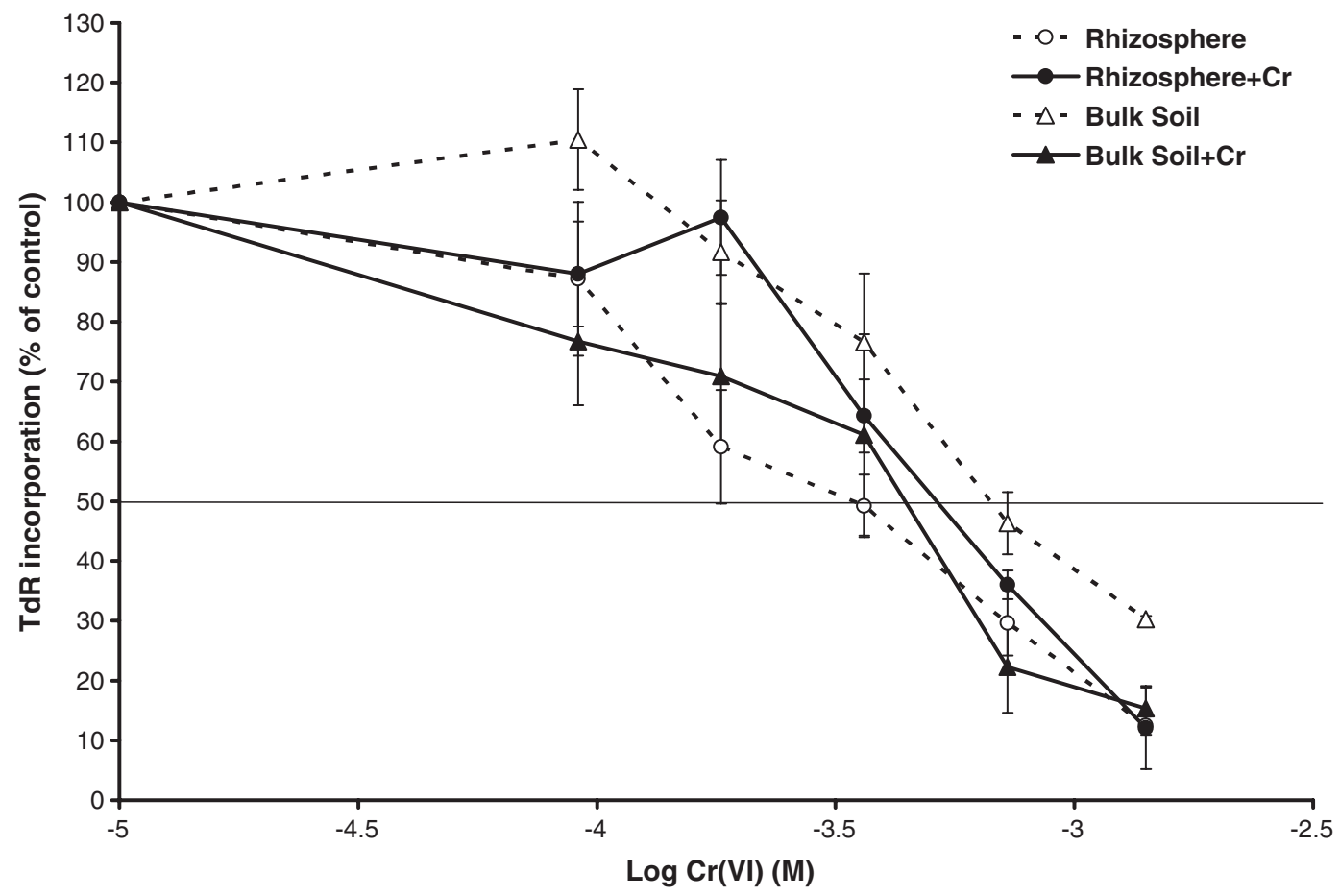

Fig. 1. Thymidine incorporation in a range of $\mathrm{Cr}$ concentrations of extracts of bulk soil, bulk soil treated with $\mathrm{Cr}$, rhizosphere, and rhizosphere soil treated with $\mathrm{Cr}$, expressed as percent of the control-tolerance indicator (error bars represent standard error, $n=3$ ). The line at $50 \%$ incorporation relative to the control is to assist in visualizing $\mathrm{IC}_{\mathbf{5 0}}$. 


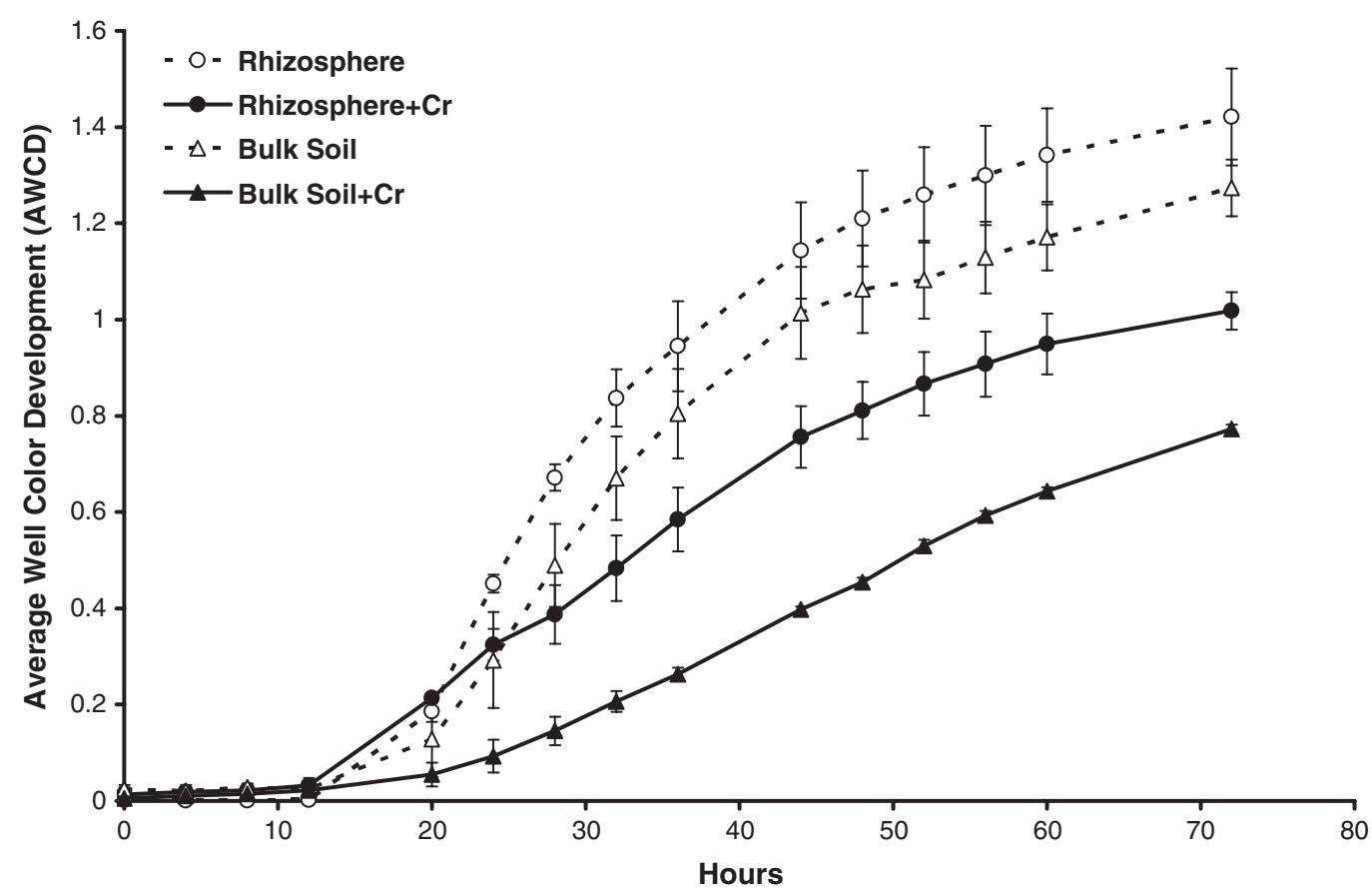

Fig. 2. Average well color development (AWCD) in BIOLOG plates for Cr-amended and unamended bulk and rhizosphere soil (error bars represent standard error, $n=3$ ). Symbols: open circles $(\bigcirc)$, rhizosphere, closed circles $(\bullet)$, rhizosphere $+C r$, open triangles $(\triangle)$, bulk soil, closed triangles ( $\mathbf{\Delta})$, bulk soil $+\mathbf{C r}$.

One of the explanations for lower biomass in metalcontaminated soils is lower efficiency of conversion of carbon into biomass (McGrath et al., 1995). However, because $\mathrm{Cr}(\mathrm{VI})$ was no longer present at significant concentrations, lower biomass could probably be explained by an initial killing impact. The higher background carbon in the non-fumigated controls of biomass mea- surements of the Cr-treated soil is evidence of such an event. The rhizosphere apparently moderates $\mathrm{Cr}$ effects; this can be due to greater substrate availability through root exudates, as well as to reduction or complexation of $\mathrm{Cr}(\mathrm{VI})$ by exudates. Rhizobia, for example, are protected by the host plant in metal-contaminated soils (Giller et al., 1998), and root exudates increased counts

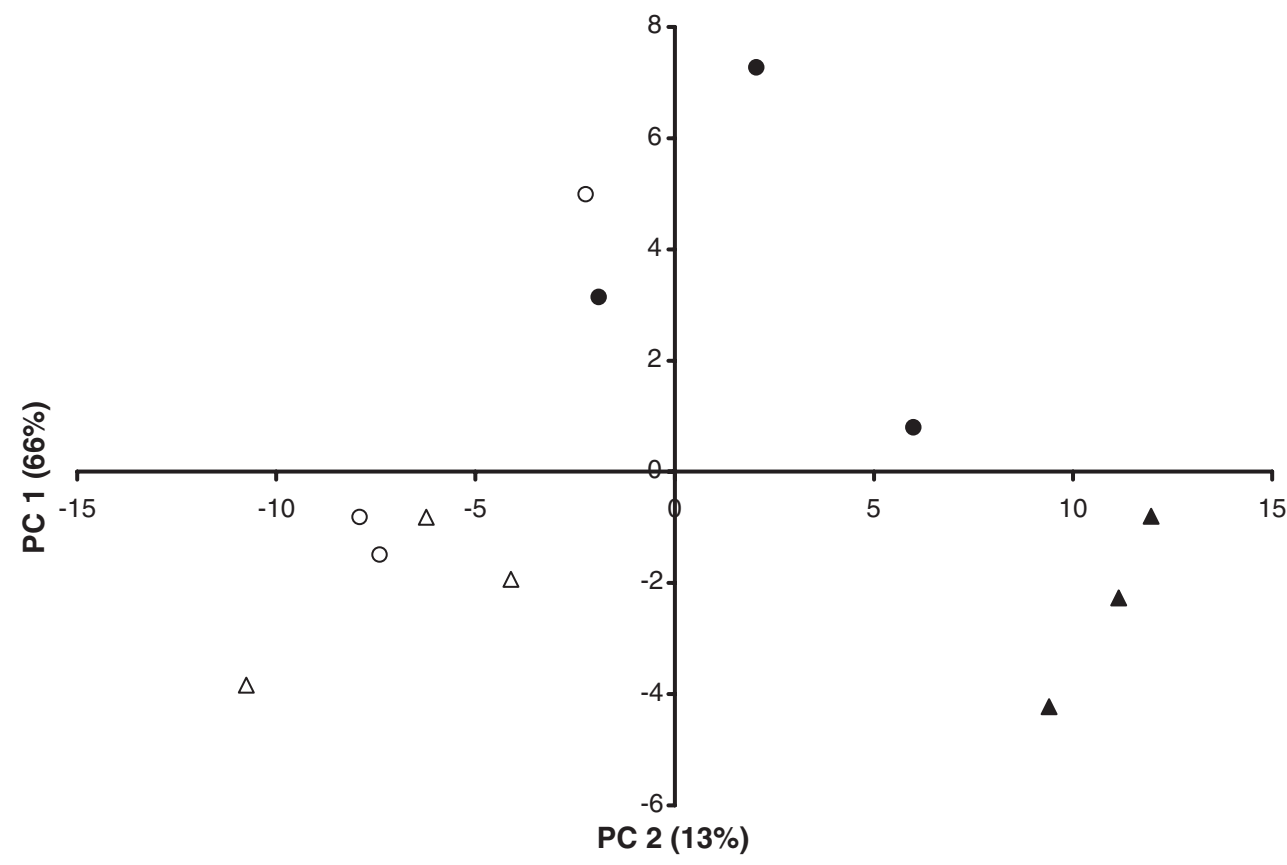

Fig. 3. Principal component analysis of BIOLOG plates data. Each point represents one replicate. Symbols: open circles $(O)$, rhizosphere, closed circles $(\bullet)$, rhizosphere $+\mathbf{C r}$, open triangles $(\triangle)$, bulk soil, closed triangles $(\Delta)$, bulk soil + Cr. Values in parentheses show the variation explained by the principal component. 
of culturable bacteria from metal-contaminated soils (Kozdrój and van Elsas, 2000).

\section{Tritiated Thymidine Incorporation}

The TdR incorporation results $\left(\mathrm{IC}_{50}\right)$ weakly indicated that prior exposure to $\mathrm{Cr}$ increased tolerance in the rhizosphere. However, the response in the bulk soil was surprisingly the opposite. It may be that in bulk soil the initial $\mathrm{Cr}$ application eliminated part of the microbial community without selection for tolerance, rendering the microbial community more sensitive to additional $\mathrm{Cr}$ application. Another explanation may have to do with the low levels of TdR incorporation in bulk soil.

Shi et al. (2002a), measuring ${ }^{3} \mathrm{H}$-leucine incorporation in a series of $\mathrm{Cr}(\mathrm{VI})$ concentrations of a microbial community extract from a site with $\mathrm{Cr}, \mathrm{Pb}$, and hydrocarbon pollution, found $\mathrm{IC}_{50}$ values of $2.5 \mathrm{~m} M \mathrm{Cr}(\mathrm{VI})$ and no differences in $\mathrm{Cr}$ tolerance regardless of exposure history. However, a non-vegetated Cr-contaminated soil from a tannery gave an $\mathrm{IC}_{50}$ value of $3.68 \mathrm{~m} M$ (Shi et al., $2002 \mathrm{~b}$ ). A possible explanation for non-development of $\mathrm{Cr}$ tolerance is that tolerance is widespread among soil microorganisms, and higher concentrations may be required to demonstrate such a difference (Giller et al., 1998). Riemann and Lindgaard-Jørgensen (1990) exposed natural seawater and fresh water samples to a range of $\mathrm{Cr}(\mathrm{VI})$ concentrations and found $\mathrm{IC}_{50}$ values ranging between 0.4 and $2.36 \mathrm{~m} M$. Viti and Giovanetti (2001), using vegetated tannery soil, found no difference in viable counts between control and $\mathrm{Cr}$-contaminated soil when low $(0.15 \mathrm{~m} M) \mathrm{Cr}(\mathrm{VI})$ levels were added to the medium, but increased counts for the Cr-contaminated sites at $1.5 \mathrm{~m} M \mathrm{Cr}(\mathrm{VI})$. However, their soil could oxidize $\mathrm{Cr}$ (III) to (VI), thus longer term exposure might be needed, as shown for ammonia-oxidizing bacteria (Gong et al., 2002), although in that case copper and arsenate were co-contaminants in addition to $\mathrm{Cr}$.

In our case, the concentration of $447 \mathrm{mg} \mathrm{kg}^{-1} \mathrm{Cr}(\mathrm{VI})$ used might not have been sufficiently high, or present sufficiently long at high concentration to induce tolerance in the bulk soil. On the other hand, Díaz-Raviña and Bååth (2001) showed that microbial communities pre-exposed to heavy metals lost tolerance within $8 \mathrm{~d}$ when they were inoculated into sterilized unpolluted soil and therefore, in this study, if there was some selection for a Cr-tolerant microbial community in the Cr-treated bulk soil near the time of impact, this may have disappeared as $\mathrm{Cr}$ concentration decreased. This would concur with the hypotheses that decreased metal tolerance and decreased metal toxicity occur with time (DíazRaviña and Bååth, 1996).

The specific TdR incorporation expressed on a per mg $\mathrm{C}$ basis, shows that there was a higher rate of thymidine incorporation rate in the Cr-treated rhizosphere and bulk soil. Higher rates of thymidine incorporation are associated with higher growth rates (Robarts and Zohary, 1993). Chromium could select for fast growing organisms indirectly. Díaz-Raviña and Bååth (1996) hypothesized that after applying heavy metals, the microorganisms that survive can thrive on the flash event derived from the $\mathrm{C}$ and other nutrients released from the metal-killed organisms. Indeed, this was evidenced by the non-fumigated Cr-treated controls, which had higher biomass $\mathrm{C}$ than the untreated soils. Thus, one type of selection can be the ability of some microorganisms to quickly utilize the $\mathrm{C}$ released after perturbation, and by means of high growth rates out-compete slowgrowing species. This difference in growth rates suggests a physiological difference of the Cr-treated microbial communities, as was suggested for chloroform-fumigated soil (Griffiths et al., 2000). Direct selection for fastgrowing organisms could also be possible if fast growth rates are associated with Cr tolerance, which should also be accompanied by an increase in metal tolerance. However, fast growth rates were not associated with an increase in Cr tolerance for the Cr-treated bulk soil.

\section{Community Substrate Use Analysis (BIOLOG GN Plates)}

The Cr treatment caused overall lower and slower color development in plate wells, which can be attributed to lower microbial biomass, because AWCD is known to be influenced by the initial inoculum density. This limitation of the BIOLOG method can account for the discrepancy between slower growth rates, as indicated with BIOLOG plates, and faster growth rates, as indicated with the STdR data. In other metal toxicity studies in which BIOLOG was used without biomass differences (Kelly and Tate, 1998), there was a lag period for the metal treatments, caused by metal toxicity. In the present study, although there was lower microbial biomass with metal addition, overall there was no lag period, which was another indication that $\mathrm{Cr}$ was no longer toxic. However, increased lag time is not always a characteristic of metal-stressed microorganisms (Giller et al., 1998).

When different inoculum densities are involved, multiple plate readings and a set value of AWCD (Garland, 1996), or the area under the curve (Guckert et al., 1996; Hackett and Griffiths, 1997), can be used for normalization. The Gini coefficient at 0.75 AWCD indicates that evenness, or functional diversity, was higher with $\mathrm{Cr}$ treatment, showing that $\mathrm{Cr}$ application not only decreased microbial biomass, but also had a qualitative impact by increasing diversity (Harch et al., 1997). If Cr, directly or indirectly, selected for fast-growing organisms (as suggested by the STdR results) a decrease in diversity would be expected. However, the initial killing impact of $\mathrm{Cr}$ could release survivors from competition, at least temporarily. Giller et al. (1998) proposed extending to microorganisms and heavy metal stress a hump-backed relationship between diversity and stress that applies to plants and animals. In that model, moderate stress increases diversity by limiting predominance of highly competitive species, thus allowing more species to proliferate. Therefore, the effects of Cr could decrease microbial biomass, induce $\mathrm{Cr}$ tolerance or select for Cr-tolerant microorganisms, select indirectly for fast-growing organisms, and increase diversity by decreasing competition (i.e., the evenness of the population would increase 
because one or more highly competitive and dominant microbial species were eliminated by the treatment).

Other transient impacts, such as fumigation, have caused a decrease in diversity by selecting for fast-growing organisms (Griffiths et al., 2000). For example, heat caused a switch in microbial community from mesophylic to thermophylic, with the mesophylic activity not recovering within the 20-d period measured (Ranneklev and Bååth, 2001). In the current study, microbial biomass was higher in the rhizosphere, and the bulk soil treatments had the same evenness as their respective rhizosphere treatments. The higher biomass in the rhizosphere most likely was because of greater nutrient availability than in the bulk soil.

Rhizosphere and bulk soil communities were distinctively separated, because they had distinct characteristics. We deduce that as an effect of the $\mathrm{Cr}$ addition, communities differentiated even more, with increased Cr tolerance (rhizosphere), selection for fast growing organisms, and increased diversity. The two parameters, $\mathrm{Cr}$ addition and the rhizosphere, resulted in a partitioning of the soil microbial communities almost on four different quartiles in the principal component analysis. It seems that $\mathrm{Cr}$ addition had a greater effect on the bulk soil than on the rhizosphere microbial community. The Cr-treated bulk soil microbial community was further from the untreated soil population in the two-dimensional principal component space than the Cr-treated rhizosphere soil from the respective untreated soil. However, this was not supported by differences in diversity between bulk and rhizosphere soil.

\section{CONCLUSIONS}

Our goal was to test current theories on the effects of heavy metals on soil microorganisms in the rhizosphere using $\mathrm{Cr}$, a metal with rather complex chemistry. One of the limitations of the study was the use of a single sample point and $\mathrm{Cr}$ concentration. Had there been no treatment differences we would have been unable to adequately test the hypothesis. Population differences might have developed early, then receded beyond detection, which could not have been determined without more frequent sampling. Population differences may have required more time than our sampling interval to manifest themselves, or required higher or lower $\mathrm{Cr}$ concentrations. However, there were observable and statistically significant differences between samples based on the types of analyses we conducted. When these differences developed, and how long they persisted, would be separate issues to investigate. We found that $\mathrm{Cr}(\mathrm{VI})$ was rendered biologically unavailable, and therefore we believe that the results represent the echo of $\mathrm{Cr}$ toxicity on the microbial community. We expected, and saw, a reduction in soil microbial biomass with $\mathrm{Cr}$ treatment. We also expected that $\mathrm{Cr}$ would decrease diversity, and increase microbial community tolerance to $\mathrm{Cr}$, especially in the rhizosphere. Ultimately, $\mathrm{Cr}$ tolerance was marginally increased in the rhizosphere, but surprisingly decreased in the bulk soil, and Cr application actually increased diversity (as measured by evenness of the popu- lation) and growth rates. This leads us to hypothesize indirect selection for fast-growing organisms accompanied with alleviation of competition among microbial communities, at least temporarily. In turn, it is tempting to assume that the system was recovering from the $\mathrm{Cr}$ application, possibly faster in the rhizosphere. But for that hypothesis to be tested, more frequent sampling of longer duration would be required than what we employed in this study. Following a transient perturbation, systems can regain their original level of function, but recovery is impaired by loss of diversity (Griffiths et al., 2000). Further studies should investigate the ability of Cr-impacted rhizosphere microorganisms to function (such as the ability to degrade organic matter), as well as longer term effects of $\mathrm{Cr}$ application.

\section{ACKNOWLEDGMENTS}

This research was supported by funds from the Kentucky Senate Bill 271 program. It is published (Manuscript No. 0406-99) with the approval of the Director of the Kentucky Agricultural Experiment Station, Univ. of Kentucky, Lexington, KY. We would also like to thank Chris Matocha and Virginia Fernandez-Canigia for their valuable input.

\section{REFERENCES}

Bååth, E. 1992. Measurement of heavy-metal tolerance of soil bacteria using thymidine incorporation into bacteria extracted after homogenization centrifugation. Soil Biol. Biochem. 24:1167-1172.

Babich, H., and G. Stotzky. 1985. Heavy-metal toxicity to microbemediated ecologic processes-A review and potential application to regulatory policies. Environ. Res. 36:111-137.

Bakken, L.R. 1985. Separation and purification of bacteria from soil. Appl. Environ. Microbiol. 49:1482-1487.

Bartlett, R.J. 1991. Chromium cycling in soils and water-Links, gaps, and methods. Environ. Health Perspect. 92:17-24.

Bartlett, R.J., and B.R. James. 1996. Chromium. p. 683-701. In D.L. Sparks et al. (ed.) Methods of soil analysis. Part 3. Chemical methods. SSSA, Madison, WI.

Bartlett, R.J., and J.M. Kimble. 1976. Behavior of chromium in soils: I. Trivalent forms. J. Environ. Qual. 5:379-383.

Carlot, M., A. Giacomini, and S. Casella. 2002. Aspects of plant-microbe interactions in heavy metal polluted soil. Acta Biotechnol. 22:13-20.

Chaney, R.L., J.A. Ryan, and S.L. Brown. 1996. Development of the USEPA limits for chromium in land-applied biosolids and applicability of these limits to tannery by-product derived fertilizers and other Cr-rich soil amendments. p. 231-295. In S. Canali, F. Tittarelli, and P. Sequi (ed.) Chromium environmental issues. FrancoAngeli, Milan, Italy.

Díaz-Raviña, M., and E. Bååth. 1996. Development of metal tolerance in soil bacterial communities exposed to experimentally increased metal levels. Appl. Environ. Microbiol. 62:2970-2977.

Díaz-Raviña, M., and E. Bååth. 2001. Response of soil bacterial communities pre-exposed to different metals and reinoculated in an unpolluted soil. Soil Biol. Biochem. 33:241-248.

Díaz-Raviña, M., E. Bååth, and A. Frostegard. 1994. Multiple heavymetal tolerance of soil bacterial communities and its measurement by a thymidine incorporation technique. Appl. Environ. Microbiol. 60:2238-2247.

Doelman, P., and L. Haanstra. 1989. Short-term and long-term effects of heavy-metals on phosphatase-activity in soils-An ecological dose-response model approach. Biol. Fertil. Soils 8:235-241.

Dushenkov, V., P.B.A.N. Kumar, H. Motto, and I. Raskin. 1995. Rhizofiltration-The use of plants to remove heavy metals from aqueous streams. Environ. Sci. Technol. 29:1239-1245.

Ellis, R.J., J.G. Best, J.C. Fry, P. Morgan, B. Neish, M.W. Trett, and A.J. Weightman. 2002. Similarity of microbial and meiofaunal community analyses for mapping ecological effects of heavy-metal contamination in soil. FEMS Microbiol. Ecol. 40:113-122. 
Garland, J.L. 1996. Analytical approaches to the characterization of samples of microbial communities using patterns of potential C source utilization. Soil Biol. Biochem. 28:213-221.

Garland, J.L., and A.L. Mills. 1991. Classification and characterization of heterotrophic microbial communities on the basis of patterns of community-level sole carbon-source utilization. Appl. Environ. Microbiol. 57:2351-2359.

Giller, K.E., E. Witter, and S.P. McGrath. 1998. Toxicity of heavy metals to microorganisms and microbial processes in agricultural soils: A review. Soil Biol. Biochem. 30:1389-1414.

Gong, P., S.D. Siciliano, S. Srivastava, C.W. Greer, and G.I. Sunahara. 2002. Assessment of pollution-induced microbial community tolerance to heavy metals in soil using ammonia-oxidizing bacteria and biolog assay. Hum. Ecol. Risk Assess. 8:1067-1081.

Griffiths, B.S., K. Ritz, R.D. Bardgett, R. Cook, S. Christensen, F. Ekelund, S.J. Sorensen, E. Bååth, J. Bloem, P.C. de Ruiter, J. Dolfing, and B. Nicolardot. 2000. Ecosystem response of pasture soil communities to fumigation-induced microbial diversity reductions: An examination of the biodiversity-ecosystem function relationship. Oikos 90:279-294.

Guckert, J.B., G.J. Carr, T.D. Johnson, B.G. Hamm, D.H. Davidson, and Y. Kumagai. 1996. Community analysis by Biolog: Curve integration for statistical analysis of activated sludge microbial habitats. J. Microbiol. Methods 27:183-197.

Haack, S.K., H. Garchow, M.J. Klug, and L.J. Forney. 1995. Analysis of factors affecting the accuracy, reproducibility, and interpretation of microbial community carbon source utilization patterns. Appl. Environ. Microbiol. 61:1458-1468.

Hackett, C.A., and B.S. Griffiths. 1997. Statistical analysis of the timecourse of Biolog substrate utilization. J. Microbiol. Methods 30:63-69.

Harch, B.D., R.L. Correll, W. Meech, C.A. Kirkby, and C.E. Pankhurst. 1997. Using the Gini coefficient with Biolog substrate utilization data to provide an alternative quantitative measure for comparing bacterial soil communities. J. Microbiol. Methods 30:91-101.

James, B.R., and R.J. Bartlett. 1983. Behavior of chromium in soils: 6. Interactions between oxidation-reduction and organic complexation. J. Environ. Qual. 12:173-176.

James, B.R., and R.J. Bartlett. 1984. Plant-soil interactions of chromium. J. Environ. Qual. 13:67-70.

Karathanasis, A.D., and A.K. Seta. 1993. Background levels of heavy metals in some Kentucky soils. Univ. of Kentucky College of Agriculture Experiment Station Bull. 727:3-19.Univ. of Kentucky, Lexington, KY

Katz, S.A., and H. Salem. 1994. The biological and environmental chemistry of chromium. VCH Publ., New York.
Kelly, J.J., and R.L. Tate. 1998. Effects of heavy metal contamination and remediation on soil microbial communities in the vicinity of a zinc smelter. J. Environ. Qual. 27:609-617.

Kozdrój, J., and J.D. van Elsas. 2000. Response of the bacterial community to root exudates in soil polluted with heavy metals assessed by molecular and cultural approaches. Soil Biol. Biochem. 32:1405-1417.

McGrath, S.P., A.M. Chaudri, and K.E. Giller. 1995. Long-term effects of metals in sewage-sludge on soils, microorganisms, and plants J. Ind. Microbiol. 14:94-104.

Nriagu, J.O., and E. Nieboer. 1988. Chromium in the natural and human environments. John Wiley \& Sons, New York.

Ranneklev, S.B., and E. Bååth. 2001. Temperature-driven adaptation of the bacterial community in peat measured by using thymidine and leucine incorporation. Appl. Environ. Microbiol. 67: $1116-1122$.

Riemann, B., and P. Lindgaard-Jørgensen. 1990. Effects of toxic substances on natural bacterial assemblages determined by means of $[3 \mathrm{H}]$ thymidine incorporation. Appl. Environ. Microbiol. 56 $75-80$.

Robarts, D., and T. Zohary. 1993. Fact or fiction-Bacterial growth rates and production as determined by [methyl-3H]-thymidine? Adv. Microb. Ecol. 13:371-425.

SAS Institute, Inc. 1989. SAS STAT users guide, version 6. SAS Institute, Inc., Cary, NC.

Shi, W., J. Becker, M. Bischoff, R.F. Turco, and A.E. Konopka. 2002a Association of microbial community composition and activity with lead, chromium, and hydrocarbon contamination. Appl. Environ. Microbiol. 68:3859-3866.

Shi, W., M. Bischoff, R. Turco, and A. Konopka. 2002b. Long-term effects of chromium and lead upon the activity of soil microbial communities. Appl. Soil Ecol. 21:169-177.

Soderberg, K.H., and E. Bååth. 1998. Bacterial activity along a young barley root measured by the thymidine and leucine incorporation techniques. Soil Biol. Biochem. 30:1259-1268.

Vance, E.D., P.C. Brookes, and D.S. Jenkinson. 1987. An extraction method for measuring soil microbial biomass C. Soil Biol. Biochem. 19:703-707.

Viti, C., and L. Giovanetti. 2001. The impact of chromium contamination on soil heterotrophic and photosynthetic microorganisms. Ann. Microbiol. 51:201-213.

Wu, J., R.G. Joergensen, B. Pommerening, R. Chaussod, and P.C Brookes. 1990. Measurement of soil microbial biomass C by fumigation extraction-An automated procedure. Soil Biol. Biochem. 22:1167-1169. 